\title{
KORUPSI BANGKRUTKAN NASIONALISME
}

\author{
Purbayu Budi Santosa \\ Fakultas Ekonomika dan Bisnis Universitas Diponegoro Semarang \\ E-mail: furifada@yahoo.com
}

Diterima 27 April 2011/Disetujui 10 Juni 2011

\begin{abstract}
Corruption index of Indonesia consistent in high position in the world. Corruption behavior spread in many aspect and this behaviour had been habit which no wrong. This situation decrease nationalism that could be used other part to take benefit from relationship between high corruption and low nationalism. This situation is not allow be continued and it must be solved by good leadership and law enforcement.
\end{abstract}

Keyword: corruption, rent seeking, leadership, law enforcement

Salah satu koran yang terbit di Hongkong menyatakan kalau orang China korupsi di bawah meja, orang India di atas meja, sedangkan orang Indonesia mejanya sekalian dibawa. Olok-olok orang Hongkong dan orang dari manca negara lainnya terhadap keadaan negara Indonesia, menyebabkan makin tenggelamnya keberadaan Indonesia dalam percaturan dunia yang semakin keras dan ganas. Kalau kita ingat kembali pada masa lalu di mana Indonesia, seperti pada jamannya Sriwijaya, Majapahit, bahkan pemerintahan Soekarno disegani berbagai negara di dunia ini, kini rasanya hanyalah tinggal kenangan belaka. Kondisi kita terjerumus pada tataran terendah, kita bukanlah pemain utama yang ikut berperan dalam percaturan dunia, akan tetapi keberadaan kita laksana pion-pion yang siap diatur dan dimakan oleh kekuatan yang lebih besar dan begitu impresif keadaannya.

Jika pendapat Prof. Arysio Santos (2009) geo$\log$ dan fisikawan nuklir Brasil benar, yang secara meyakinkan membuktikan pendapat Plato tentang hilangnya Atlantis sebagai negara surga dunia, yang pada akhirnya memunculkan negara Indonesia. Santos berhasil membantah para pakar terkemuka di dunia, bahwa cerita Plato bukan isapan jempol dan rekaan belaka, akan tetapi senyatanya ada. Temuan Santos yang begitu mengagetkan adalah pusat peradaban dunia berada di Indonesia, bukan negara lainnya.

Penduduk Atlantis asalnya secara umum begitu kaya, mulia, tenteram, damai dan berbudi luhur. Mereka tidak mementingkan kekayaan, akan tetapi lebih mementingkan kebajikan dan kesalehan. Antara rakyat dan para pemimpinnya terjadi kepercayaan yang sangat tinggi, karena orientasinya kepada tugas dan peran masing-masing di mana para pemimpin berhasil memajukan rakyatnya. Lambat laun menurut Plato penduduk Atlantis terperangkap kesombongan, ambisi, iri hati dan tidak mementingkan etika dan moralitas. Hukum-hukum Tuhan dilanggarnya, tidak samanya perkataan dan perbuatan, sehingga marahlah penguasa jagat raya ini, di mana banjir bandang terjadi, gunung-gunung berapi berpolah, dan tsunami terjadilah di mana air laut pasang sampai seratus meter lebih. Cerita akhirnya hilanglah benua Atlantis dan memunculkan negara makmur tak terdandingi Indonesia.

Seringnya terjadinya bencana alam akhir-akhir ini baik berupa banjir bandang, gunung meletus dan juga tsunami merupakan tanda-tanda seperti digambarkan Plato tentang marahnya Tuhan terhadap perilaku kita semua yang menyimpang, utamanya para pemimpin yang seharusnya sebagai pedoman dan contoh, justru melakukan kesalahan. Sekiranya para pemimpin menduduki jabatannya dengan cara tidak benar, yang berarti kepemimpinannya begitu jelek, maka khawatirnya peringatan Plato yang disuarakan secara meyakinkan oleh Santos, akan menjadi kenyataan (Purbayu BS, "Drama Pemimpin Indonesia", dalam Suara Merdeka, 30 April 2010).

Rendahnya posisi Indonesia dalam percaturan dunia dalam soal pemberantasan korupsi nampak 
dalam laporan Lembaga Tranparency Internasional yang dalam tahun 2010 meluncurkan skor IPK (Indeks Persepsi Korupsi), di mana kedudukan Indonesia tidak berubah dibandingkan tahun 2009 yaitu pada skor 2,8 (posisi nomor 110). Skor Indonesia sama dengan berbagai negara seperti Benin, Bolivia, Gabon, Kosova dan Kepulauan Solomon. Negara Indonesia kalah dengan skor negara-negara tetangga seperti Singapura $(9,3)$, Brunei $(5,5)$, Malaysia $(4,4)$ dan Thailand $(3,5)$. Meskipun begitu Indonesia lebih baik dari Vietnam $(2,7)$, Philipina $(2,4)$, Kamboja $(2,1)$, Laos $(2,1)$ dan Myanmar $(1,4)$.

Posisi Indonesia yang tetap bertahan dibandingkan tahun lalu menunjukkan bahwa dalam percaturan internasional dan negara-negara tetangga (Asean), Indonesia korupsinya masih tergolong tinggi. Kinerja pemberantaran korupsi dapat dikatakan jalan ditempat atau stagnan karena dalam lingkup nasional saja dapat dilihat masih membahananya berbagai kasus korupsi dan masih banyaknya kasus korupsi yang tidak tuntas penyelesaiannya.

Pada tataran nasional kita masih ingat bagaimana proses penyelesaian kasus Bank Century yang tidak jelas tindak kelanjutannya. Kasus rekening gendut perwira tinggi Polri, kasus Gayus Tambunan yang penyelesaiannya terlihat karut marut, maupun kasus banyaknya rekening liar di masing-masing departemen yang penanganan kasusnya kelihatannya tidaklah memuaskan. Khusus di Jawa Tengah saja, kasus rekruetmen CPNS disinyalir dibisniskan, belum lagi dari Kejaksaan Tinggi Jateng mengklaim telah memproses 186 kasus tindak pidana korupsi. Kerugian negara yang timbul sekitar Rp 94,3 miliar, akan tetapi baru Rp 4,5 miliar atau 4,7 persen yang berasil diselamatkan.

\section{Kebohongan Berjamaah}

Filosof Inggris Lord Acton (1843-1902) berpendapat :"Power tend to corrupt, and absolute power corrupts absoulutely". Pendapat Acton kiranya banyak relevannya, di mana orang yang mempunyai kekuasaan tanpa pembatas yang jelas dan ampuh, cenderung akan menyalahkan kekuasaan yang dimilikinya. Belum lagi untuk kasus Indonesia, di mana Denys Lombart yang meneliti perdagangan orangorang Asia di Samudera Hindia dan Laut Cina pada abad 13-19, menemukan bukti bahwa bangsa Nusantara hanya mampu sebagai penguasa jalur-jalur ekonomi, dan bukan sebagai pelaku ekonomi. Artinya yang dilakukan oleh kebanyakan bangsa kita pada waktu itu adalah mengharapkan retribusi (upeti) dari para pengguna jasa pelayaran, bukan sebagai seorang wiraswastawan (saudagar). Studi Sutherland tentang elite politik di Jawa juga menunjukkan hasil yang kurang lebih serupa. "Dalam pergantian kekuasaan", ungkap Sutherland, "Hanya kulit luarnya saja yang berubah, intinya tetap saja sama yaitu siapa yang berkuasa, siapa yang mendapat keuntungannya".

Dari hasil penelitian tersebut dikuatirkan kebanyakan dari para pemimpin kita berpikiran jangka pendek, bukan mempunyai misi dan visi untuk jangka panjang. Yang penting proyek jalan, dengan demikian keuntungan ekonomi bagi segelintir kelompok dapat diselenggarakan (kolusi), tanpa mempertimbangkan kegunaannya bagi rakyat banyak. Maraknya kasus kolusi itu dibuktikan dengan banyaknya pemimpin kita yang harus berurusan dengan pengadilan (Purbayu BS, 2010).

Pendefinisian mengenai masalah korupsi bukanlah barang yang mudah. Wu (2003, dalam Nugroho SBM, 2010) menyatakan mengapa masalah korupsi sulit didefinisikan. Salah satu alasannya korupsi sangat terkait dengan budaya suatu masyarakat. Contohnya, pemberian kenang-kenangan kepada sesama rekan bisnis atau dari kaum bisnis kepada pejabat publik dalam masyarakat Barat yang sangat ketat memegang hukum serta pendekatan hubungan bisnis bersifat formal dan business like, bisa dikategorikan sebagai suap atau korupsi. Tetapi bagi masyarakat Timur seperti China, Korea dan Taiwan pemberian seperti itu dianggap sebagai hal biasa karena hubungan bisnis yang lebih bersifat informal dan personal (tradisi seperti itu disebut sebagai quanxi).

Dilihat dari kacamata ilmu ekonomi yang lebih bertumpu kepada pencapaian efisiensi, perbuatan korupsi (suap) terdapat dua pandangan yang saling bertolak belakang. Pertama, efficiency grease hypotesis yang berpendapat korupsi (suap) dapat menciptakan alokasi sumberdaya secara efisien dalam suatu perekonomian. Suap yang dilakukan oleh suatu pihak dapat dianggap sebagai biaya transaksi, asal pemberiannya tidak terlalu besar maka dianggap dapat memotong jalur birokrasi, sehingga terdapat anggapan bahwa birokrasi bersifat eksogen. Kelompok lain penentangnya, beranggapan bahwa korupsi (suap) justru akan menurunkan tingkat efisiensi, karena birokrasi dapat ditentukan secara endogen oleh pihak-pihak yang berkepentingan dengan motivasi memaksimalkan besarnya korupsi yang dapat diperoleh.

Kalau kita berkiblat kepada aliran ekonomi kelembagaaan dengan pendekatan holistik (terlebih sistem Ekonomi Syariah), maka perbuatan korupsi 
(suap) merupakan tindakan yang tercela dan berimplikasi dosa. Terlebih lagi bagi negara Indonesia yang posisi korupsi masih pada papan atas tingkat mondial dan sudah menggurita dalam masyarakat, maka perilaku korupsi begitu mengganggu pencapaian efisiensi dalam perekonomian. Belum lagi, munculnya asimetrik informasi dan disparitas kemampuan tiap-tiap orang berakibat kepada memusatnya dampak korupsi pada masyarakat bawah, yakni masyarakat yang identik dengan asimetrik informasi dan rendahnya kualitas sumber daya insaninya. Dampak paling kentara dari praktik korupsi adalah lebarnya jarak ketimpangan, diiringi oleh semakin tingginya angka kemiskinan dan pengangguran.

Dalam bingkai otonomi daerah, masifnya korupsi yang ada pada suatu daerah menyebabkan munculnya berbagai kebohongan yang teramat mengerikan. Begawan ekonomi Soemitro Djojohadikusumo (alm) mengatakan kebocoran realisasi pembangunan pada zaman Orba sudah mencapai angka 30 persen. Sekarang ini angkanya belum diketahui secara pasti, akan tetapi patut diduga dengan keras angkanya beragam pada masing-masing daerah kabupaten/kota. Kalau dahulu korupsi yang begitu tinggi dilakukan oleh pemerintah pusat, namun sekarang ini besar kemungkinan bisa merembes ke berbagai daerah.

Perhatikan pada pemilihan kepala desa (pilkades) sebagai pemerintahan di tingkat paling bawah, sudah banyak dipenuhi oleh praktik jual beli suara. Apalagi pada pemilihan pimpinan di tingkat atasnya. Bisa diduga semakin berperannya uang dibandingkan kompetensi yang dimiliki untuk menduduki suatu jabatan. "Tempatkan orang sesuai keahliannya" (The righ man/woman on the right place) sesuai dengan doktrin manajemen bisa mampat, sehingga pola kerjanya asal-asalan dan tidak profesional.

Tampilan angka-angka statistik bisa jadi melenceng jauh, demi untuk mewartakan kinerja pemerintahannya yang baik. Para ahli statistik saat menggunakan alat analisisnya, besar kemungkinan akan terjadi dispersi yang cukup jauh. Padahal jika perencanaan pembangunan menggunakan basis angka statistik yang bias, sudah pasti pelaksanaannya pun akan melencenceng dari sasaran. Kalau pada suatu lembaga sangat dibutuhkan data pokok untuk perencanaan, karena pada akhirnya berujud pokoknya data, maka hanya kebohongan semata yang ada. Pelaksanaan yang salah sasaran akan merugikan banyak pihak dan bisa saja hanya segelintir orang yang diuntungkan.

Kesannya target-target pembangunan berhasil dicapai, tetapi kalau ditelisik lebih dalam citra itu belum tentu benar. Mestinya para penyelenggara pemerintah, birokrat-teknokrat insyaf dengan ada- gium: Suara rakyat adalah suara Tuhan. Bohong terhadap rakyat berarti sama dengan telah mengkhianati Tuhan. Kalau sudah begitu, tentu resiko yang bakal ditanggung oleh seorang pemimpin (pemerintah) yang melanggengkan kebohongan sangat besar dan berat (Purbayu BS, 2010).

Segala bentuk korupsi ternyata telah merusak segala sendi kehidupan berbangsa dan bernegara, sehingga rasa nasionalisme mengalami penurunan drastis. Kalau pada jaman Orba dikatakan korupsinya berjamaah, sekarang ini bersaff-saff. Dominasi korupsi dahulu ada pada pemerintahan pusat, sekarang ini karena otonomi daerah, maka sudah merambah ke mana-mana. Sangatlah tidak logis gaji bupati/walikota secara resmi antara Rp 5-6 juta per bulan, akan tetapi untuk menjadi orang nomor satu di daerah dapat memakan biaya sampai puluhan miliar. Akibatnya untuk mengembalikan biaya yang sudah dikeluarkan, maka pengembaliannya sudah barang tentu penuh nuansa korupsi.

Bahaya korupsi sudah banyak menjalar ke pikiran kita semua, maka tindakan menghalalkan cara sudah pasti akan merebak ke mana-mana, yang penting tujuan dapat tercapai ada pun caranya tidaklah penting. Menabrak ke sana ke mari, melanggar hukum sekali pun tidaklah mengapa asal sampai apa yang direncanakan. Budaya hedonisme, materialisme dan sekularisme akan melingkupi kita semua. Pada titik itu apa yang dikatakan dengan apa yang yang dikerjakan bisa sangat senjang. Balon penyakit kejiwaan dan patologi sosial semakin lama semakin menggelembung.

\section{Adakah Solusinya?}

Kegagalan pembangunan yang terjadi di Indonesia dan banyak negara sedang berkembang adalah munculnya oligarkhi kekuasaan di mana negara dikuasai oleh sekelompok orang yang terdiri dari penguasa dan pedagang. Mereka bekerja sama saling menguntungkan untuk menjalankan roda pemerintahan, yang secara tidak langsung terperangkap oleh hegemoni negara maju. Dalam ranah ilmu ekonomi kerjasama yang menguntungkan segelintir orang, sedangkan pihak publik kebanyakan dirugikan disebut sebagai kegiatan mencari rente (rent seeking activity).

Bantuan asing diberikan dalam rangka penguasaan negara lain dengan memakai strategi budaya, di mana disengaja dibiarkan bantuannya dikorupsi supaya tidak dapat melunasi utangnya. Ketika sudah tidak dapat melunasi utangnya, tinggal sebagai kom- 
pensasinya harus menurut kemauan pemikiran negara maju dan sumber dayanya yang begitu melimpah dikuasainya. Tentunya penguasaan ini tetap dibarengi dengan utang baru, yang lagi-lagi penggunaannya terjadi penyelewengan yang besar (Perkins, 2005 dan Easterly, 2006).

Hungtington (1996) menyebutnya sekarang terjadi perang peradaban dan ideologi, sedangkan Khamenei (2005) menyebutnya perang kebudayaan. Tetapi yang jelas penyebaran pengaruh dilakukan secara intens melalui jasa kemajuan bidang teknologi dan informasi. Melalui media ini berbagai segi yang ada pada pihak Barat terus saja dikampanyekan, mereka harus dianggap unggul sementara yang berbau lokal terus diwartakan sebagai terbelakang. Rasa rendah diri yang ada pada bangsa Indonesia akibat penjajahan yang demikian lama, ditambah lagi dengan budaya upeti yang ada, maka melalui pendekatan budaya korupsi makin meraja lela.

Rasa rendah diri dan terlalu mengagumi kepada pihak asing sebagai refleksi dari jiwa "inlander", menyebabkan bangsa dan negara Indonesia sangat bergantung dan merasa inferior terhadap negara maju. Para pengambil kebijakan dan para akademisi Indonesia begitu gandrung dengan pemikiran pihak asing, yang sebenarnya juga asing bagi kita semua, akan tetapi karena terus-menerus diberikan, dipelajari dan dijejali maka lama ke lamaan terkena sindrom membenarkan segala sesuatu yang dari asing. Kepunyaan kita sendiri dianggap kurang berharga (inferior), sementara yang berasal dari pihak lain dianggapnya lebih unggul (superior). Jebakan perangkap seperti ini yang berusaha dikuak dan diingatkan oleh ibunda Obama, yang sebagian besar hidupnya justru berada di Indonesia. Sebagai antropolog yang bergaul dengan kalangan luas di Indonesia, beliau begitu paham dengan segala seluk beluk orang Indonesia, baik segi kelebihan maupun kekurangannya (Purbayu BS, "Ibunda Obama dan Ekonomi Kerakyatan, dalam Jawa Pos, 16 November 2010).

Sungguh menarik mencermati ungkapan Menteri Luar Negeri Malaysia, Syed Hamid Albar (lihat Soepriyatno, 2008), yang dengan jujur mengatakan Malaysia banyak belajar dari Indonesia. Paling tidak negara jiran tersebut belajar tentang dua hal, pertama Malaysia terinspirasi oleh semangat nasionalisme dan revolusioner bangsa Indonesia. Kedua, Malaysia juga belajar dan berterima kasih pada guru-guru dari Indonesia, yang telah mengajar murid-murid dan guru-guru Malaysia.

Bukan hanya Malaysia, M. Yunus, peraih hadiah Nobel Perdamaian dari Bangladesh pun mengaku terinspirasi kita. Ia mengembangkan Grameen Bank yang berfokus pada kredit mikro bagi masyarakat ekonomi lemah, karena melihat cara kerja Bank Rakyat Indonesia (BRI) yang memberikan berbagai kredit perdesaan dengan tanggung-renteng, yang mencerminkan hidupnya tolong menolong dan gotong royong sebagai modal sosial asli Indonesia.

Menarik kalau kita cermati pidato pengukuhan antropolog Achmad Fedyani Saifuddin sebagai guru besar UI pada tanggal 24 Januari 2007, adalah perlunya mencari ada apa di balik angka statistik kemiskinan. Kemiskinan pada lapisan bawah menurutnya bukan hanya merupakan kumpulan angka dan data, akan tetapi sebagai refleksi budaya. Yang didapatkannya adalah moralitas yang kurang baik pada para petinggi menurun pada para bawahan berujud budaya menerabas, yang dapat merusak sendi-sendi kehidupan berbangsa. Kemiskinan pada lapisan bawah disebabkan oleh belum adanya kesempatan untuk melakukan aneka bentuk korupsi, sehingga kalau ada kesempatan maka akan dilakukan karena bercermin kepada atasannya sebagai teladan yang tersesat dalam etika dan moralitas.

Ajip Rosidi (2009) berpendapat bahwa kesalahan terbesar dari berbagai pemerintahan di Indonesia adalah pada masa rejim Orba, karena corak kepemimpinannya yang begitu otoriter dan penuh nuansa korupsi. Hal ini bukan berarti pada masa Orla tidak ada korupsi, karena korupsi sebenarnya di mana pun di dunia ini pasti ada, hanya saja tingkat intensitasnya yang berbeda dan hal itu sangat tergantung bagaimana para petinggi menyikapinya.

Korupsi pada masa Orla sifatnya masih individual, paling hanya melibatkan satu dua orang lain yang dekat dengan pelaku korupsi. Pada waktu itu intensitas korupsinya tidak mungkin tinggi, karena posisi keuangan negaranya masih amat terbatas. Kekayaan sumberdaya alam Indonesia belum dieksploitasi secara serius, seperti minyak bumi, ikan di laut, hutan maupun sumber kekayaan alam lainnya.

Krisis enerji pada tahun 1970-an menyebabkan harga minyak bumi membumbung begitu tingginya. Ekspolitasi minyak waktu itu dilakukan begitu intensif dengan mengajak pihak luar negeri, yang termasuk juga upaya secara masif penebangan kayu dan penangkapan ikan-ikan di laut dengan menggunakan 
teknologi yang termasuk moderen. Derasnya aliran uang yang masuk ke pundi-pundi pemerintahan ditambah lagi dengan pinjaman uang dari berbagai negara donor, sehingga menyebabkan begitu kayanya Indonesia waktu itu. Gaji pegawai negeri pada waktu itu sebenarnya dapat dipatok demikian tinggi, akan tetapi oleh pemerintah hal ini tidak dilakukan. Kesalahan pengambilan keputusan tersebut, menyebabkan kesalahannya berlarut-larut hingga sekarang.

Pemerintah pada waktu itu tidak memberikan gaji yang layak kepada pegawai negeri, sebaliknya justru memberikan kesempatan untuk melakukan tindakan korupsi melalui "proyek-proyek" yang diadakan. Akibatnya terdapat korelasi yang positif antara kedudukan posisi jabatan dengan tambahan pendapatan. Semakin posisinya strategis dalam suatu jabatan maka pendapat tambahan (sabetan) akan semakin besar, dan semakin rendah kedudukannya maka pendapatan tambahan semakin kecil.

Reformasi biokrasi sebenarnya telah dilakukan pada berbagai instansi, dan yang paling mencolok pada departemen keuangan. Sayangnya meskipun telah dilakukan perbaikan struktur gaji pada instansi tersebut, akan tetapi kasus Gayus sebagai pegawai yang masih termasuk yunior, ternyata melakukan tindakan korupsi yang demikian tinggi. Harapan pemberantasan korupsi yang ada sebenarnya terletak pada KPK, akan tetapi kedudukan KPK sekarang ini cukup memprihatinkan karena bukti nyata adanya manfaat lembaga ini berusaha untuk dikikis sampai tataran terendah. Virus korupsi yang sudah demikian mewabah, tentunya akan berusaha memberantas segala kebaikan dan kebajikan yang ada.

Tetapi percayalah dosa warisan yang demikian membelenggu kemajuan Indonesia, harus benarbenar dapat dihilangkan, supaya dapat ke luar dari perangkap lingkaran setan yang demikian menjerumuskan. Kebaikan akan selalu menang di atas kejahatan, meskipun butuh waktu dan perlu kerja keras dari segala unsur masyarakat. Reformasi lembaga pemerintahan, termasuk dalam tubuh kepolisian dan berbagai lembaga yang berkaitan dengan penegakan hukum harus dilakukan guna menuju Indonesia yang maju dan berkeadilan.

Kita mesti belajar dari negara China yang dahulunya tingkat korupsinya tinggi akan tetapi dengan kepemimpinan yang tegas dan konsisten, maka segala aneka rupa korupsi dapat ditekan ke tataran rendah. Adalah perdana menteri China, Zhu Rongji, yang dilantik pada bulan Maret 1998, dapat dipandang sebagai salah satu pelopor kemajuan negara yang mendapat julukan tirai bambu. Beliau mengatakan, "Untuk melenyapkan korupsi, saya menyiapkan 100 peti, sembilan puluh sembilan untuk para koruptor dan satu untuk saya bila saya terbukti berbuat korupsi". Dengan diberantasnya korupsi, maka dusta di antara kita di China tidak muncul, yang terjadi sekarang ini negara China menjadi salah satu negara terpandang dan termaju di dunia.

Sudah saatnya sekarang para pemimpin Indonesia mempunyai jiwa kepemimpinan yang baik dan profesional, disertai tingkat kejujuran yang tinggi dalam artian kerja sebagai amanah dengan moralitas dan etika yang tinggi. Bagi bangsa dan negara Indonesia para pemimpin adalah sebagai anutan dan cermin bagi masyarakatnya, apabila beliau baik akan dituruti, tetapi kalau jelek juga akan diikuti, meski pun dapat terjadi karena faktor keterpaksaan. Para pemimpin harus selaras dan serasi antara yang diucapkan dan diperbuatnya, sehingga penelitian UIN Syarif Hidayatullah dapat terbantahkan di mana tidak ada korelasinya antara ibadah vertikal dan sosial (Abdi Kunia Djohan, "Komitmen Antikorupsi", dalam Republika, 5 Februari 2010).

Kalau di negara tirai bambu para koruptor yang terbukti salah akan dihukum mati, termasuk para petingginya, maka sekiranya Indonesia dapat melakukannya, dalam waktu yang tidak terlalu lama dapat menjadi macan Asia bahkan dunia. Rasa cinta akan kebangsaan dan negara Indonesia, yang menunjukkan bangkitnya rasa nasionalisme, akan segera terjadi. Jadilah para pemimpin bagaikan para pengembala yang menjaga domba-dombanya dari serangan serigala, bukan lantas para elite yang justru menjadi serigala. Sekiranya itu yang dilakukan, bukan tidak mustahil drama tenggelamnya negara Atlantis, yang kalau benar Indonesia, maka akan terjadi. Semoga hal tersebut tidak terjadi dan marilah kita semua terlebih-lebih untuk para pemimpinnya untuk bertaubat, di mana kerja adalah sebagai amanah Tuhan yang semestinya harus dijalankan sebaik-baiknya. 


\section{DAFTAR PUSTAKA}

Abdi Kunia Djohan, "Komitmen Antikorupsi”, dalam Republika, 5 Februari 2010

Ajip Rosidi .2009. Korupsi dan Kebudayaan. Jakarta: Pustaka Jaya.

Bambang Wisudo, et al. 2010. Sekolah Harapan Sekolah Bebas Korupsi. Jakarta:ICW

Easterly, William. 2006. The White Man's Burden. New York: The Penguin Press.

HCB Dharmawan dan Al Soni de Rosari (ed). 2004. Surga Para Koruptor. Jakarta: Kompas.

Ibrahim Z, Fahmi Bodoh dan Abdullah Dahlan. 2010. Korupsi Pemilu di Indonesia. Jakarta: ICW dan Tifa.

Nugroho SBM. 2010. "Determinan Penyuapan pada Perusahaan Menengah dan Besar di Jawa Tengah”. Proposal disertasi. Semarang: Program Pascasarjana UNDIP.

Perkins, John. 2005. Confessions of an Ecomic Hit Man. Terjemahan. Herman Tirtaatmaja dan Dwi Karyani. Jakarta: Abdi Tandur.

Purbayu Budi Santosa. 2010. Kegagalan Aliran Ekonomi Neoklasik dan Relevansi Aliran Ekonomi Kelembagaan dalam Ranah Kajian Ilmu Ekonomi. Pidato Pengukuhan Guru Besar FE UNDIP, 11 Maret 2010. Semarang: Badan Penerbit Universitas Diponegoro.
Purbayu Budi Santosa. 2010. Politik Beras dan Beras Politik, Buntelan Opini Terseleksi tentang Politik Pertanian, Kemandirian, dan Pembangunan. Semarang: Badan Penerbit Universitas Diponegoro.

Purbayu Budi Santosa, "Drama Pemimpin Indonesia", dalam Suara Merdeka, 30 April 2010.

Purbayu Budi Santosa, "Ibunda Obama dan Ekonomi Kerakyatan, dalam Jawa Pos, 16 November 2010.

Saifuddin Zuhri. 1981. Sejarah Kebangkitan Islam dan Perkembangannya di Indonesia. Bandung: Alma'arif.

Soepriyatno. 2008. Nasionalisme dan Kebangkitan Ekonomi. Jakarta: Inside Press. 